\begin{tabular}{|lcc|}
\hline \multicolumn{3}{|c|}{ TOTOBUANG } \\
\hline Volume 6 & Nomor 1, Juni 2018 & Halaman $155-167$ \\
\hline
\end{tabular}

\title{
RELASI KEKERABATAN BAHASA HITU, WAKAL, MORELA, MAMALA, DAN HILA DI PROVINSI MALUKU \\ (The Family Relationship Language Hitu, Wakal, Morela, Mamala, and Hila in Maluku Province)
}

\author{
Taufik \\ Universitas Iqra Buru \\ Jl. Prof. Dr. H. A.R. Basalamah No. 20, Namlea, Buru \\ Pos-el: taufiksalamun@gmail.com
}

(Diterima: 19 April 2018; Direvisi: 30 Mei 2018; Disetujui: 04 Juni 2018)

\begin{abstract}
This study aimed to describe the cognate words based on the determined criterion of relative word and determine the percentage of kinship towords Hitu, Wakal, Morela, Mamala, and Hila language. This study used descriptive qualitative and quantitative approach. The data were collected through interview techniques and field note method. The data that had been obtained were classified and described qualitatively and quantitatively by using calculational lexicostatistic formula. The results showed that the pair of relative word in the language of Hitu, Wakal, Morela, Mamala, and Hila could be reviewed by the pairs of identical, correspondences phonemic, phonetic resemblance, a different phoneme, and deleted phonemes. Based on the calculational lexicostatistic, the percentage of Hitu-Hila language kinship was in the highest level of kinship, which wa $90 \%$ and had been categorized as a dialect. While the lowest percentage of kinship wasWakal-Morela with the percentage of kinship about $77 \%$ and had been categorized as sub-family language.

Keywords: phonemes, kinship percentage, lexicostatistics
\end{abstract}

\section{Abstrak}

Penelitian ini bertujuan untuk mendeskripsikan kata-kata kognat berdasarkan kriteria penentuan kata kerabat dan menentukan tingkat persentase kekerabatan bahasa Hitu, Wakal, Morela, Mamala, dan Hila. Jenis penelitian ini bersifat deskriptif dengan pendekatan kualitatif dan kuantitatif. Data dikumpulkan melalui metode pupuan lapangan dengan teknik wawancara dan catat. Data yang telah diperoleh kemudian diklasifikasi dan selanjutnya dideskripsikan secara kualitatif dan kuantitatif dengan menggunakan rumus perhitungan leksikostatistik. Hasil penelitian menunjukkan bahwa pasangan kata kerabat pada bahasa Hitu, Wakal, Morela, Mamala, dan Hila dapat ditinjau berdasarkan pasangan kata identik, korespondensi fonemis, kemiripan secara fonetis, satu fonem beda, dan pelesapan fonem. Berdasarkan perhitungan leksikostatistik, persentase kekerabatan bahasa Hitu-Hila menduduki tingkat kekerabatan tertinggi, yaitu 90\% dan dikategorikan sebagai satu bahasa dialek. Sedangkan persentase kekerabatan terendah, yaitu bahasa Wakal-Morela dengan persentase kekerabatan sebesar 77\% dan dikategorikan sebagai subkeluarga bahasa.

Kata-kata kunci: fonem, persentase kekerabatan, leksikostatistik

\section{PENDAHULUAN}

Bahasa dapat mengatur berbagai macam aktivitas kemasyarakatan, merencanakan dan mengarahkan masa depan seseorang. Meskipun kita tahu bahwa masih ada alat komunikasi lain seperti gerak tubuh, bunyi-bunyian, lukisan-lukisan, dan semacamnya, tetapi bahasa merupakan alat komunikasi yang lebih tepat dan efektif.
Hal di atas membuktikan bahwa bahasa memiliki peranan yang penting bagi kehidupan manusia. Begitu pentingnya bahasa (Taufik, 2017) menyatakan bahwa ketika seorang pembicara menggunakan bahasa yang tidak dipahami dalam komunikasi maka pesan yang disampaikan oleh pembicara tidak akan sampai kepada pendengar. Hal tersebut Sesuai dengan pendapat Keraf (2004) yang menuturkan 
bahwa bahasa merupakan saluran perumusan maksud kita, melahirkan perasaan kita dan memungkinkan kita menciptakan kerja sama dengan sesama warga. Begitupula dengan bahasa-bahasa yang tersebar di seluruh wilayah nusantara.

Hampir setiap daerah yang ada di Indonesia memiliki bahasa daerah dan dialeknya sendiri. Bahasa dan dialek tersebut digunakan untuk berkomunikasi antarsesama masyarakat di tiap daerah tersebut. Oleh sebab itu, bahasa dapat dijadikan sebagai salah satu ciri yang menunjukkan identitas suatu bangsa atau daerah. Melalui bahasa, orang dapat mengidentifikasi kelompok masyarakat tertentu, mengenali perilaku, dan kepribadian masyarakat penuturnya, serta mengenali budayanya.

Berkaitan dengan hal di atas, Alijah (2016) menyatakan bahwa bahasa-bahasa daerah ini merupakan salah satu unsur kebudayaan Indonesia yang perlu terus dipelihara dan dilestarikan. Hal ini sesuai dengan UUD Republik Indonesia Nomor 24 tahun 2009 Pasal 1 ayat 6 yang berbunyi: "Bahasa daerah adalah bahasa yang digunakan secara turun temurun oleh warga Indonesia di daerah-daerah di wilayah Negara Kesatuan Republik Indonesia”. Oleh sebab itu, negara dan warganya wajib memelihara, mengembangkan, dan melestarikan bahasa-bahasa daerah agar nilai-nilai budaya yang terkandung didalamnya tetap utuh dan tetap memainkan perannya sebagai salah satu aset kebudayaan nasional.

Alwi dan Sugono (dalam Simon, 2015) menyatakan bahwa bahasa daerah adalah bahasa yang dipakai sebagai bahasa perhubungan intradaerah atau intramasyarakat selain bahasa Indonesia yang dipakai sebagai sarana pendukung sastra serta budaya daerah atau masyarakat etnik di wilayah Republik Indonesia. Demikian juga dengan masyarakat pemakai bahasa Hitu, Wakal, Morela, Mamala, dan Hilayang tersebardi wilayah Jazirah Leihitu, Kabupaten Maluku Tengah, Provinsi
Maluku yang menggunakan bahasa daerahnya dalam berkomunikasi antarpemakai bahasa yang sama.

Bahasa-bahasa daerah di atas merupakan bahasa yang terdapat pada desa atau negeri yang secara geografis letaknya saling berdekatan, yakni Negeri Hitu, Wakal, Morela, Mamala, dan Hila. Kedekatan negeri-negeri tersebut memungkinkan adanya kontak bahasa dan budaya sehingga dapat saling memengaruhi. Hal itu memungkinkan adanya persamaan antarbahasa-bahasa di atas, utamanya dalam bidang fonologi dan leksikon. Dalam bidang fonologi persamaan tersebut dapat berupa cara artikulasi, misalnya kata jalan. Kata ini pada bahasa Hitu memiliki bentuk lalan dan pada bahasa Mamala memiliki bentuk lalay. Kedua kata tersebut memiliki fonem akhir yang berbeda, yaitu $/ \mathrm{n} / \mathrm{dan} / \mathrm{y} /$. Meskipun berbeda, namun kedua fonem tersebut samasama berada pada posisi artikulasi yang sama, yaitu nasal. Sementara itu, dalam bidang leksikon terdapat bentuk yang sama, misalnya kata berjalan. Kata ini pada bahasa Wakal, Hitu, dan Morela memiliki bentuk leksikon yang sama, yaitu oi.

Menurut Sudarno (1994) hampir semua bahasa di Indonesia memiliki kesamaan atau kemiripan bentuk dan makna antarsatu bahasa dengan bahasa yang lain. Hal ini menunjukkan adanya hubungan atau relasi antarbahasa-bahasa yang dipakai pada desa-desa yang saling berdekatan. Oleh sebab itu, analisis kualitatif dengan jalan pendeskripsian fenomena kebahasaan dan analisis kuantitatif dalam linguistik komparatif dilakukan dengan menerapkan teknik leksikostatistik untuk melihat relasi kekerabatan bahasa Hitu, Wakal, Morela, Mamala, dan Hila. Johnson (2008) mendeskripsikan metode analisis kuantitatif dengan teknik leksikostatistik yang digunakan dalam kajian linguistik diakronis dengan 200 kosakata dasar Swadesh sebagai ukuran dari keseluruhan kosakata bahasa yang dikaji. Teknik leksikostatistik merupakan teknik sederhana yang secara 
statistik untuk memperkirakan derajat perbedaan linguistik antara bahasa-bahasa berkerabat (Trask, 2000).

Pemetaan tingkat kekerabatan tersebut merupakan gambaran sebagian besar kehidupan sosial dan budaya masyarakat Maluku yang multilingual, yang secara pasti menimbulkan situasi kebahasaan yang sedikit rumit. Oleh sebab itu, melalui penelitian ini penulis mencoba memecahkan masalah tersebut dengan menentukan status (bahasa, dialek, dan subdialek) antara bahasa Hitu, Wakal, Morela, Mamala, dan Hila dengan mendeskripsikan kata-kata kognat yang berdasarkan pada kriteria penentuan kata-kata kerabat. Tahap selanjutnya adalah menentukan tingkat persentase bahasabahasa tersebut. Pengamatan kedua hal itu akan dilakukan dengan pendekatan leksikostatistik sebagai salah satu metode pengelompokan bahasa yang lebih awal, cepat, hemat, dan handal (Langgole, 1997).

Selanjutnya, dari penelitian ini diharapkan dapat menjadi salah satu sumber informasi pada bidang kebahasaan, terutama yang ada kaitannya dengan bidang pengelompokan bahasa-bahasa tertentu yang ada di Provinsi Maluku.Hasil penelitian ini juga diharapkan dapat dijadikan sebagai bahan masukan bagi pihak-pihak yang berwenang dalam bidang pembinaan dan pengembangan bahasa untuk menyusun strategi pengembangan dan pembinaan bahasa di masa mendatang.

\section{LANDASAN TEORI}

Salah satu bidang ilmu yang mempersoalkan keadaan atau kondisi bahasa-bahasa di dunia adalah Linguistik Historis Komparatif (LHK). Keraf (1996) mengatakan bahwa Linguistik Bandingan Historis (Linguistik Historis Komparatif) adalah salah satu cabang dari ilmu bahasa yang mempersoalkan bahasa dalam bidang waktu serta perubahan-perubahan unsur bahasa yang terjadi dalam bidang waktu tersebut. Salah satu kepentingan Linguistik Historis Komparatif adalah mengadakan pengelompokkan (sub-grouping) bahasabahasa dalam suatu rumpun bahasa. Bahasa dalam satu rumpun sama belum tentu sama pada tingkat kekerabatan atau sama tingkat kemiripannya satu sama lain.

Kridalaksana (2008) menuturkan bahwa kekerabatan adalah hubungan antara dua bahasa atau lebih yang diturunkan dari sumber bahasa induk yang sama atau yang biasa disebut bahasa purba. Bahasa berkerabat adalah bahasa yang memiliki hubungan antara bahasa yang satu dengan yang lain. Hubungan ini bisa jadi merupakan asal atau induk yang sama sehingga terdapat kemiripan atau karena adanya ciri-ciri umum yang sama. Dalam hal bahasa kemiripan itu terlihat dari segi fonologi, morfologi, dan sintaksis.

Lebih lanjut Keraf (1996) menambahkan bahwa bahasa-bahasa kerabat yang berasal dari proto yang sama selalu akan memperlihatkan kesamaan-kesamaan berikut:

1. Kesamaan sistem bunyi (fonetik) dan susunan bunyi (fonologis);

2. Kesamaan morfologis, yaitu kesamaan dalam bentuk kata dan kesamaan dalam bentuk gramatikal;

3. Kesamaan sintaksis, yaitu kesamaan relasinya antara kata-kata dalam sebuah kalimat.

Dalam membandingkan dua bahasa atau lebih dapat digunakan teknik leksikostatistik, yaitu salah satu metode pengelompokan bahasa yang banyak dipakai oleh para pakar atau peneliti bahasa di dunia. Menurut Sulistyono (2015) teknik leksikostatistik merupakan salah satu alat analisis dalam penelusuran linguistis yang memanfaatkan metode komparatif. Metode pengelompokan ini mengamati hubungan kekerabatan dua bahasa atau lebih yang berdasarkan pada kosakatanya. Selanjutnya dari kosakata yang berkerabat tersebut dituangkan dalam bentuk statistik yang berupa angka-angka.

Menurut Wacana

leksikostatistik adalah suatu teknik dalam 
pengelompokan bahasa yang lebih cenderung dan lebih mengutamakan peneropongan kata-kata (leksikon) secara statistik, untuk kemudian berusaha menetapkan pengelompokan itu berdasarkan persentase kesamaan dan perbedaan suatu bahasa dengan bahasa lain. Sejalan dengan itu, menurut Nothofer (1990) penentuan tingkat kekerabatan bahasa-bahasa yang dianalisis dengan menggunakan metode leksikostatistik memiliki beberapa keunggulan jika dibandingkan dengan metode-metode lain. Keunggulankeunggulan tersebut, yaitu (1) sebagai daftar kosakata dasar yang cepat dapat menentukan hubungan kekerabatan bahasa yang kerabat, (2) sebagai alat pengelompokan bahasa (dialek) yang sekerabat yang proto bahasanya belum begitu tua (kuno), dan (3) sebagai alat (metode) yang dapat dipakai pada tahap awal menetapkan klasifikasi bahasa.

Penetapan kosakata kerabat dapat dilakukan dengan prosedur sebagai berikut:

a. Jika sebuah kata terdapat morfem terikat, morfem tersebut harus dipisahkan, kemudian baru dibandingkan kemiripan atau kesamaannya.

b. Penetapan kosakata kerabat dapat dilakukan dengan kriteria: (1) pasangan kosakata itu identik, (2) pasangan kosakata itu berkorespondensi fonemis, (3) adanya kemiripan secara fonetis, (4) satu fonem berbeda, (5) pelesapan fonem.

c. Penyusunan matriks persentase kekerabatan untuk mempermudah penentuan sub grouping mikro, hasil perhitungan kosakata kerabat dimasukan dalam matriks.

Secara garis besar leksikostatistik memiliki tiga asumsi/pendirian dasar, yaitu (1) kosakata dasar diganti dengan kecepatan yang sama pada semua bahasa pada waktu yang sama. Asumsi ini beranggapan bahwa setiap 1000 tahun atau sekitar 18-20\% kosakata dasar berubah pada semua bahasa secara serentak, (2) semua kosakata dasar yang terdapat pada daftar kosakata dasar kemungkinan kata-kata itu terganti secara serentak, dan (3) ada yang disebut kosakata dasar yang dianggap berlaku umum pada semua bahasa (Nothofer, 1990).

Menurut Surbakti (2014) dalam membandingkan kata-kata untuk menetapkan kata-kata mana yang merupakan kata kerabat dan mana yang tidak, maka perlu dikemukakan lagi suatu asumsi lain dalam metode perbandingan, yaitu: fonem bahasa proto yang sudah berkembang secara berlainan dalam bahasa-bahasa kerabat, akan berkembang terus secara konsisten dalamlingkungan linguististiap-tiap bahasa kerabat. Oleh sebab itu, penetapan kosakata yang dianggap kognat perlu mempertimbangkan kemungkinan adanya kosakata yang merupakan pinjaman dari bahasa-bahasa lain, misalnya bahasa Melayu dan bahasa-bahasa lain yang berpengaruh di lokasi sekitar, seperti bahasa Belanda dan Portugis.Selain itu, harus mempertimbangkan kata-kata yang merupakan tiruan bunyi (onomatope), kata bayi (nursery words), dan kata-kata yang kebetulan mirip dalam penetapan status kekognatan kata, sehingga didapatlah katakata yang kognat.

Jumlah kosakata yang kognat tersebutdapat menentukan persentase tingkat kekerabatan antara bahasa-bahasa yang dibandingkan. Penentuan tersebut dilakukan berdasarkan perhitungan dengan menggunakan rumus dalam leksikostatistik, yaitu rumus untuk mencari tingkat persentase hubungan kekerabatan bahasabahasa yang dianalisis. Setelah diperoleh persentase kekerabatan, status kekerabatan antarbahasa ditentukan sesuai dengan kriteria penetapan relasi genetis antarbahasa yang dikemukakan oleh Crowley (2010). 
Tabel 1

Pembagian Tingkatan Persentase Kekerabatan Antarbahasa

\begin{tabular}{|l|l|}
\hline \multicolumn{1}{|c|}{ Level Pengelompokan } & \multicolumn{1}{c|}{ PersentaseKognat } \\
\hline Bahasa Dialek (dialect of language) & $81-100 \%$ \\
\hline Subkeluarga Bahasa (Language of Subfamily) & $61-81 \%$ \\
\hline Keluarga Bahasa (Language of family) & $36-81 \%$ \\
\hline Keturunan Keluarga Bahasa (Family of stock) & $12-36 \%$ \\
\hline Keturunan Mikrofilium (stock of Microphylum) & $4-12 \%$ \\
\hline Mesofilium & $1-4 \%$ \\
\hline Makrofilium & $0-1 \%$ \\
\hline
\end{tabular}

Berdasarkan tabel pengelompokan bahasa di atas,hubungan kekerabatan antarbahasa dapat diketahui melalui perhitungan persentase kekerabatan. Persentase kekerabatan antarbahasa tersebut dapat dijadikan acuan dalam pengelompokan bahasa Hitu, Wakal, Morela, Mamala, dan Hila.

\section{METODE PENELITIAN \\ Jenis Penelitian dan Pendekatan}

Penelitian ini merupakan penelitian deskriptif dengan pendekatan kualitatif dan kuantitatif.Pendekatan kualitatif digunakan untuk menjelaskan fenomena kebahasaan berdasarkan pada kriteria penentuan kata kerabat. Sementara itu, pendekatan kuantitatif digunakan untuk menentukan persentase kekerabatan bahasa Hitu, Wakal, Morela, Mamala, dan Hila dengan menerapkan rumus perhitungan leksikostatistik.

\section{Metode dan Teknik Pengumpulan Data}

Metode pengumpulan data yang dipakai pada penelitian ini adalah metode pupuan lapangan (metode lapangan langsung). Teknik yang dapat digunakan untuk menunjang metode pupuan lapangan adalah teknik wawancara dan catat. Dalam penelitian ini digunakan 200 daftar kosakata dasar Morris Swadesh sebagai instrumen penelitian. Selanjutnya, kata-kata tersebut ditanyakan kepada informan tiap-tiap bahasa yang dianalisis, yaitu bahasa Hitu, Wakal, Morela, Mamala, dan Hila. Pemilihan informan penelitian berdasarkan pada kriteria: (1) penutur asli dari bahasa yang diteliti, (2) berdomisili pada lokasi penelitian, (3) tidak memiliki cacat pada artikulasinya, (4) berusia antara 30-60 tahun, (5) memiliki waktu yang cukup untuk menjawab setiap pertanyaan (Djajasudarma dalam Wahyu, 2013).Hasil dari pengumpulan tersebut selanjutnya dijadikan sebagai data penelitian.

\section{Teknik Analisis Data}

Data yang telah diperoleh melalui wawancara, dianalisis melalui tahap, mengidentifikasi kata-kata yang kognat, mengklasifikasi data berdasarkan kriteria penentuan kata kerabat yang terdiri atas kata identik, korespondensi fonemis, kemiripan secara fonetis, dan pelesapan fonem. Data yang telah diklasifikasi, dideskripsikan berdasarkan kriteria penentuan kekerabatan tersebut. Melalui hasil deskripsi akan diperoleh jumlah kata kognat dari tiap-tiap bahasa yang dianalisis, yakni bahasa Hitu, Wakal, Morela, Mamala, dan Hila.

Setelah diperoleh jumlah kata kognat, tahap selanjutnya adalahdata dianalisis dengan menggunakan metode leksikostatistik. Teknik ini memakai angkaangka sebagai dasar pemilihannya. Untuk menghitung persentase kata kognat dapat digunakan rumus berikut ini.

$$
\mathrm{c}=\frac{\mathrm{g}}{\mathrm{n}} \times 100 \%
$$


keterangan:

$$
\begin{aligned}
& \mathrm{C}=\text { Persentase kerabat } \\
& \mathrm{g}=\text { Jumlah kata kognat } \\
& \mathrm{n}=\text { Total glos }
\end{aligned}
$$

\section{PEMBAHASAN}

Berdasarkan pada pemerolehan data maka dapat dideskripsikan kata-kata kerabat bahasa Hitu, Wakal, Morela, Mamala, dan Hila berdasarkan empat kriteria penentuan kata kerabat yang dikemukakan oleh Keraf
(1996). Selanjutnya dari hasil penentuan kriteria tersebut dapat ditentukan tingkat persentase bahasa-bahasa yang dianalisis. Berikut hasil analisis kekerabatan bahasa Hitu, Wakal, Morela, Mamala, dan Hila.

\section{Kata Identik}

Pasangan kata dikatakan identik apabila semua fonem dari pasangan kata tersebut sama betul. Berikut pasangan kata pada bahasa Hitu, Wakal, Morela, Mamala, dan Hila yang memiliki pasangan kata identik.

Tabel 2

Pasangan Kata Identik

\begin{tabular}{|c|c|c|c|c|c|}
\hline Gloss & Hitu & Wakal & Morela & Mamala & Hila \\
\hline datang & lai & lai & lai & lai & lai \\
\hline jauh & lau & lau & lau & lau & lau \\
\hline engkau & ale & ale & ale & ale & ale \\
\hline merah & kau & kau & kau & kau & kau \\
\hline rambut & keul & keul & keul & keul & keul \\
\hline
\end{tabular}

Pada tabel 2 tampak bahwa dari kelima bahasa yang dianalisis, kata-kata tersebut memiliki fonem dan urutan yang sama atau identik. Hal itu dapat dilihat pada kata datang. Kata ini pada bahasa Hitu, Wakal, Morela, Mamala, dan Hila memiliki bentuk yang sama, yaitu lai yang terdiri atas susunan /l/, /a/, /i/. Selanjutnya kata jauh pada kelima bahasa yang dianalisis tersebut memiliki bentuk yang sama atau identik, yaitu lau yang terdiri atas susunan /l/, /a/, /u/. Kata selanjutnya yang bentuknyasama atau identikdari kelima bahasa yang dianalisis adalah kata engkau yang dalam kelima bahasa tersebut sama-sama memiliki bentuk ale yang terdiri atas susunan /a/, /l/, /e/. Kata lainnya yang bentuknyasama atau identikdari kelima bahasa tersebut adalah kata merah. Kata ini dalam kelima bahasa itu sama-sama memiliki bentuk kau yang terdiri atas susunan /k/, /a/, /u/. Kata selanjutnya yang samaatau identik dari tabel 2 pada bahasa Hitu, Wakal, Morela, Mamala, dan Hila adalah rambut. Kata ini pada kelima bahasa tersebut memiliki bentuk yang sama, yaitu keul yang terdiri atas susunan /k/, /e/, /u/, /l/.

\section{Korespondensi Fonemis}

Bila perubahan fonem antara pasangan kata itu terjadi secara timbal-balik dan teratur, serta besar frekuensinya, bentuk yang berimbang antara pasangan kata tersebut dianggap berkerabat. Berikut pasangan kata pada bahasa Hitu, Wakal, Morela, Mamala, dan Hila yang berkorespondensi fonemis.

Tabel 3

Pasangan Kata yang Berkorespondensi Fonemis

\begin{tabular}{|c|c|c|c|c|c|}
\hline Gloss & Hitu & Wakal & Morela & Mamala & Hila \\
\hline beberapa & yi:la & i:la & yi:la & wai:la & waila \\
\hline tahu & kewa & ke:wa & kewan & tewa & kewa \\
\hline
\end{tabular}




\begin{tabular}{|c|c|c|c|c|c|}
\hline duduk & ko:lo & kolo & ko:lo & tolo & kolo \\
\hline mereka & sile & sile & yile & sile & sile \\
\hline air bah & henel & henel & henen & henen & henel \\
\hline
\end{tabular}

Kata pada tabel 3 yang mengalami korespondensi fonem adalah kata beberapa. Kata ini pada bahasa Hitu dan Morela memiliki bentuk yang sama, yaitu yi:layang terdiri atas susunan/y/, /i/, ///, /a/. Kata yila mengalami korespondensi fonem pada bahasa Mamala dan Hila menjadi waila yang terdiri atas susunan /w/, /a/, /i/, /l/, /a/. Korespondensi yang terjadi yaitu /y/ pada bahasa Hitu-Morela berkorespondensi dengan /wa/ pada bahasa Mamala dan Hila. Sedangkan pada bahasa Wakal kata yila dan waila mengalami pelesapan fonem menjadi ila yang terdiri atas susunan /i/, /1/, /a/.

Selanjutnya kata yang mengalami korespondensi fonem pada tabel 3 tampak pada kata tahu. Kata tersebut memiliki bentuk yang sama pada bahasa Hitu, Wakal, dan Hila, yakni kewayang terdiri atas susunan/k/, /e/, /w/, /a/. Sementara itu, kata kewa pada bahasa Morela mendapat penambahan $/ \mathrm{y} /$ di akhir kata menjadi kewayyang terdiri atas susunan /k/, /e/, /w/, /a/, /y/. Kata kewa mengalami korespondensi fonem pada bahasa Mamala menjadi tewa yang terdiri atas susunan $/ \mathrm{t} / \mathrm{h} / \mathrm{e} / \mathrm{,} / \mathrm{w} / \mathrm{l} / \mathrm{a} /$. Berdasarkan penjabaran tersebut korespondensi yang terjadi, yaitu /k/ pada bahasa Hitu, Wakal, Hila, dan Morela berkorespondensi dengan /t/ pada bahasa Mamala.

Kata lainnya yang mengalami korespondensi fonem pada tabel 3 tampak pada kata duduk. Kata tersebut memiliki bentuk yang sama pada bahasa Hitu, Wakal, Morela, dan Hila, yaitu kolo yang terdiri atas susunan/k/, /o/, /l/, /o/. Sementara itu, kata kolo mengalami korespondensi fonem di awal kata pada bahasa Mamala menjadi tolo yang terdiri atas susunan $/ \mathrm{t} /, / \mathrm{o} /, / \mathrm{l} /, \mathrm{lo} /$. Berdasarkan penjabaran tersebut korespondensi yang terjadi, yaitu $/ \mathrm{k} /$ pada bahasa Hitu, Wakal, Hila, dan Morela berkorespondensi dengan /t/ pada bahasa Mamala.

Pada tabel 3, kata lainnya yang mengalami korespondensi fonem adalah kata mereka. Kata ini pada bahasa Hitu, Wakal, Mamala, dan Hila memiliki bentuk yang sama, yaitu sile yang terdiri atas susunan fonem /s/, /i/, /l/, /e/. Pada bahasa Morela kata sile mengalami korespondensi fonemis di awal kata menjadi yile yang terdiri atas susunan fonem /y/, /i/, /l/, /e/. Korespondensi yang terjadi pada kelima bahasa tersebut adalah /s/ pada kata sile berkorespondensi dengan /y/ pada kata yile.

Kata berikutnya yang mengalami korespondensi fonem adalah kata air bah. Kata ini pada bahasa Hitu, Wakal, dan Hila memiliki bentuk yang sama, yaitu henel yang terdiri atas susunan $/ \mathrm{h} /, / \mathrm{e} /, \mathrm{ln} /, \mathrm{e} / \mathrm{l}, / \mathrm{l} /$. Kata tersebut pada bahasa Morela dan Mamala mengalami korespondensi fonemis di akhir kata menjadi heney yang terdiri atas susunan /h/, /e/, /n/, /e/, /n/. Korespondensi yang terjadi, yaitu /l/ pada kata henel berkorespondensi dengan / $/ \mathrm{y} /$ pada kata heney.

\section{Kemiripan secara Fonetis}

Bila tidak dapat dibuktikan bahwa sebuah pasangan kata dalam kedua bahasa itu mengandung korespondensi fonemis, tetapi pasangan kata itu ternyata mengandung kemiripan secara fonetis dalam posisi artikulatoris yang sama, pasangan itu dapat dianggap sebagai kata kerabat. Yang dimaksud dengan mirip secara fonetis adalah ciri-ciri fanetisnya harus cukup serupa sehingga dapat dianggap sebagai alofon.Berikut pasangan kata pada bahasa Hitu, Wakal, Morela, Mamala, dan Hila yang memiliki kemiripan secara fonetis. 
Tabel 4

Pasangan Kata yang Mirip secara Fonetis

\begin{tabular}{|c|c|c|c|c|c|}
\hline Gloss & Hitu & Wakal & Morela & Mamala & Hila \\
\hline angin & anin & anin & anin & anin & Anin \\
\hline itu & na & ma & ya & ma & Ma \\
\hline lempar & keri & teri & keri & keri & Keri \\
\hline bintang & ma:lin & bintan & ma:rin & ma:rin & Malin \\
\hline bapak & baba & papa?u & baba & baba & Papa \\
\hline
\end{tabular}

Pada tabel 4 pasangan kata yang mirip secara fonetis dapat dilihat pada kata angin. Kata tersebut dalam bahasa Hitu dan Wakal memiliki bentuk yang sama, yaitu anin yang terdiri atas susunan /a/, /n/, /i/, /n/. Bentuk lain yang sama terdapat pula pada bahasa Morela, Mamala, dan Hila, yaitu aniy yang terdiri atas susunan $/ a /, / n /, / i /, / y /$. Antara bentuk anin dan aniy memiliki perbedaan bentuk fonem di akhir kata, yaitu /n/ dan /y/. Meskipun demikian kedua kata ini masih dikategorikan kerabat karena kedua fonem yang berbeda tersebut berada pada posisi cara artikulasi yang sama, yaitu nasal.

Kata selanjutnya pada tabel 4 yang mirip secara fonetis dapat dilihat pada kataitu. Kata tersebutpada bahasa Hitu memiliki na yang terdiri atas susunan /n/, /a/. Pada bahasa Morela memiliki bentuk $\eta a$ yang terdiri atas susunan $/ \mathrm{y} /$, /a/. Sementara itu, pada bahasa Wakal, Mamala, dan Hila memiliki bentuk yang sama, yaituma yang terdiri atas susunan /m/, /a/. Ketiga bentuk tersebut memiliki fonem awal yang berbeda, yaitu $/ \mathrm{y} /$, /y/, dan /m/. Meskipun demikian katana,ya, dan ma masih berkerabat karena ketiga fonem yang berbeda tersebut berada pada posisi cara artikulasi yang sama, yaitu nasal.

Kata berikutnya yang mirip secara fonetis pada tabel 4 adalah kata lempar. Kata ini dalam bahasa Hitu, Morela, Mamala, dan Hila memiliki bentuk yang sama, yaitu keri yang terdiri atas susunan fonem $/ \mathrm{k} / \mathrm{l} / \mathrm{e} /, \mathrm{r} / \mathrm{r}$, /i/. Sedangkan pada bahasa Wakal memiliki bentuk teri yang terdiri atas susunan $/ \mathrm{t} / \mathrm{l} / \mathrm{e} /$, /r/, /i/. Di awal kata, bentuk keri dan teri memiliki bentuk fonem yang berbeda, yaitu /k/ dan /t/. Meskipun fonem awal kedua kata itu berbeda, namun kedua kata tersebut masih dikategorikan kerabat karena fonem /k/ dan /t/ masih berada pada posisi cara artikulasi yang sama, yaitu hambat (letup).

Selanjutnya pada tabel 4, kata yang mirip secara fonetis adalah kata bintang. Kata ini pada bahasa Morela dan Mamala memiliki bentuk yang sama, yaitu ma:riy yang terdiri atas susunan fonem $/ \mathrm{m} /, / \mathrm{a} /, / \mathrm{r} /$, /i/, /y/. Pada bahasa Hitu memiliki bentuk ma:linyang terdiri atas susunan $/ \mathrm{m} /, \mathrm{a} /, / \mathrm{l} /$, /i/, /n/, bahasa Hila memiliki bentuk malig yang terdiri atas susunan $/ \mathrm{m} /, / \mathrm{a} /, / 1 /, / \mathrm{i} /, / \mathrm{y} /$. Kata ma:riy, ma:lin, dan maliy memiliki bentuk fonem yang berbeda di tengah kata, yaitu /r/ dan /1/. Meskipun fonem tengah ketiga kata tersebut berbeda, namun ketiga kata itu masih berkerabat karena /r/ dan /1/ berada pada tempat artikulasi yang sama, yakni apikoalveolar.

Pada tabel 4kata selanjutnya yang mirip secara fonetis adalah kata bapak. Kata tersebutmemiliki persamaan fonem di tiga bahasa, yaitu bahasa Hitu, Morela, dan Mamala, yakni kata baba yang terdiri atas susunan /b/, /a/, /b/, /a/. Sementara itu, pada bahasa Wakal memiliki bentukpapa?uyang terdiri atas susunan /p/, /a/, /p/, /a/, /?/, /u/dan bahasa Hila memiliki bentukpapa yang terdiri atas susunan /p/, /a/, /p/, /a/. Kata baba, papa?u, dan papa memiliki fonem yang berbeda di awal kata, yaitu /b/ dan $/ \mathrm{p} /$. Meskipun fonem awal ketiga kata tersebut berbeda, namun ketiganya masih dikategorikan kerabat karena /b/ dan /p/ 
masih berada pada tempat artikulasi yang sama, yakni bilabial.

\section{Satu Fonem Berbeda}

Bila dalam satu pasangan kata terdapat perbedaan satu fonem, tetapi perbedaan itu dapat dijelaskan terjadi karena pengaruh lingkungan yang dimasukinya, sedangkan dalam bahasa lain pengaruh lingkungan itu tidak mengubah fonemnya maka pasangan kata tersebut dapat ditetapkan sebagai kata kerabat. Berikut pasangan kata pada bahasa Hitu, Wakal, Morela, Mamala, dan Hila yang satu fonemnya berbeda.

Tabel 5

Pasangan Kata yang Satu Fonemnya Berbeda

\begin{tabular}{|c|c|c|c|c|c|}
\hline Gloss & Hitu & Wakal & Morela & Mamala & Hila \\
\hline Berat & mahe:la & mahela & yahela & mahela & Mahela \\
\hline Besar & ne:la & nela & ne:la & ne:la & ne:la \\
\hline Hujan & u:lan & u:lan & $\mathrm{u}: \operatorname{la\eta }$ & u:lan & u:lan \\
\hline telinga & tari:na & tali:nai & tari:na & tari:na & tari:na \\
\hline Lain & sahan & sahan & sahay & sahay & Laen \\
\hline
\end{tabular}

Kata pada tabel 5 yang satu fonemnya berbeda dapat dilihat pada kata berat. Kata ini memiliki bentuk yang sama pada bahasa Hitu, Wakal, Mamala, dan Hila, yaitu mahela yang terdiri atas susunan $/ \mathrm{m} /, / \mathrm{a} /, \mathrm{h} /$, /e/, /l/, /a/. Sementara itu, kata berat pada bahasa Morela memiliki bentuk yahela yang terdiri atas susunan //y/, /a/, /h/, /e/, /l/, /a/. Kata mahela dan yahela memiliki satu fonem yang berbeda di awal kata, yaitu $/ \mathrm{m} /$ pada kata mehela dan / $\mathrm{y} /$ pada kata yahela.

Pasangan kata berikutnya pada tabel 5 yang satu fonemnya berbeda adalah kata besar. Kata ini memiliki bentuk yang sama pada bahasa Hitu, Morela, Mamala, dan Hila, yaitu ne:la yang terdiri atas susunan $/ \mathrm{n} /$, /e/, /1/, /a/. Sementara itu, pada bahasa Wakal memiliki bentuk nela yang terdiri atas susunan /n/, /e/, /l/, /a/. Kedua kata tersebut memiliki satu fonem yang berbeda di awal kata, yaitu /n/ pada kata nela dan /n/ pada kata nela.

Selanjutnya kata yang satu fonemnya berbeda pada tabel 5, yaitu kata hujan. Kata ini pada bahasa Hitu dan Wakal memiliki bentuk yang sama, yaitu $u$ :lan yang terdiri atas susunan /u/, /l/, /a/, /n/. Sementara itu, pada bahasa Morela, Mamala, dan Hila memiliki bentuk u:lay yang terdiri atas susunan u/, /l/, /a/, /y/. Kedua kata tersebut memiliki satu fonem yang berbeda di akhir kata, yaitu fonem /n/ pada kata $u$ :landan /n/ pada kata $u: l a \eta$.

Kata lainnya yang satu fonemnya berbeda pada tabel 5 adalah kata telinga. Kata ini pada bahasa Hitu, Morela, Mamala, dan Hila memiliki bentuk yang sama, yaitu tari:na yang terdiri atas susunan /t/, /a/, /r/, /i/, /n/, /a/. Sementara itu, pada bahasa Wakal memiliki bentuk ta:linai yang terdiri atas susunan /t/, /a/, /l/, /i/, /n/, /a/, /i/. Kedua kata tersebut memiliki satu fonem yang berbeda di tengah kata, yaitu /r/ pada kata tarina dan /1/ pada kata talinai.

Kata berikutnya pada tabel 5 yang satu fonemnya berbeda adalah kata lain. Kata ini pada bahasa Hitu dan Wakal memiliki bentuk yang sama, yaitu sahan yang terdiri atas susunan /s/, /a/, /h/, /a/, /n/. Sementara itu, bentuk yang sama pula ditunjukkan pada bahasa Morela dan Mamala, yaitu sahay yang terdiri atas susunan /s/, /a/, /h/, /a/, /y/ sedangkan bentuk yang berbeda terdapat pada bahasa Hila, yaitu laen yang terdiri atas susunan /l/, /a/, e/, /y/. Kata sahan pada bahasa Hitu dan Wakal memiliki satu fonem yang berbeda di akhir kata dengan kata sahay pada bahasa Morela dan Mamala, yaitu $/ \mathrm{n} /$ dan $/ \mathrm{y} /$. 


\section{Pelesapan Fonem}

Berikut pasangan kata pada bahasa Hitu, Wakal, Morela, Mamala, dan Hila yang mengalami pelesapan fonem.

Tabel 6

Pasangan Kata yang Mengalami Pelesapan Fonem

\begin{tabular}{|c|c|c|c|c|c|}
\hline Gloss & Hitu & Wakal & Morela & Mamala & Hila \\
\hline $\mathrm{aku}$ & yau & iyau & $\mathrm{au}$ & $\mathrm{au}$ & Yau \\
\hline (ber-) kelahi & pahiya & pahiya & ahiya & pahiya & Pahiya \\
\hline cium (bau) & pahanisu & pani:su? & panesu?i & pahanisu & Pahanisu \\
\hline gigi & ni:ki & nikin & ni:ki & ni:ki & Nikin \\
\hline main & pahai & pahai & pahaen & ahai & Pahai \\
\hline
\end{tabular}

Berdasarkan pada tabel 6pelesapan fonem tampak pada kata $a k u$. Kata tersebut dalam bahasa Hitu dan Hila memiliki bentuk yang sama yaitu yau yang terdiri atas susunan /y/, /a/, /u/. Sedangkan pada bahasa Wakal mendapat penambahan /i/ di awal kata sehingga menjadi iyau yang terdiri atas susunan /i/, /y/, /a/, /u/. Kata yau dan iyau yang mengalami pelesapan fonem pada bahasa Morela dan Mamala adalah /y/ dan /i/ sehingga kata tersebut menjadi au yang terdiri atas susunan /a/, /u/.

Kata lainnya yang mengalami pelesapan fonem pada tabel 6 adalah (ber-) kelahi. Kata tersebut pada bahasa Hitu, Wakal, Mamala, dan Hila memiliki bentuk yang sama, yaitu pahiya yang terdiri atas susunan /p/, /a/, /h/, /i/, /y/, /a/. Pada bahasa Morela kata ini mengalami pelesapan fonem di awal kata, yaitu /p/ sehingga menjadi ahiya yang terdiri atas susunan /a/, /h/, /i/, /y/, /a/.

Kata selanjutnya yang mengalami pelesapan fonem pada tabel 6 adalah cium (bau). Kata tersebut memiliki bentuk yang sama pada bahasa Hitu, Mamala, dan hila yaitu pahanisu yang terdiri atas susunan $/ \mathrm{p} /$, /a/, /h/, /a/, /n/, /i/, /s/, /u/. Pada bahasa Wakal dan Morela kata pahanisu mengalami pelesapan fonem di tengah kata, yaitu $/ \mathrm{h} /$ dan /a/ sehingga pada bahasa Wakal menjadi pani:su? yang terdiri atas /p/, /a/, /n/, /i/, /s/, /u/. Pada bahasa Morela selain mengalami pelesapan fonem, terdapat pula perubahan fonem di tengah kata, yaitu /i/ menjadi /e/ dan terdapat penambahan /i/ di akhir kata sehingga menjadi panesu?i yang terdiri atas susunan /p/, /a/, /n/, /e/, /s/, /u/, /i/.

Selanjutnya, kata yang mengalami pelesapan fonem adalah kata gigi. Kata ini pada bahasa Wakal dan Hila memiliki bentuk yang sama, yaitu nikiø yang terdiri atas susunan fonem /n/, /i/, /k/, /i/, /n/. Pada bahasa Hitu, Morela, dan Mamala kata nikin mengalami pelesepan $/ \mathrm{y} /$ pada akhir kata sehingga menjadi ni:ki yang terdiri atas susunan /n/, /i/, /k/, /i/.

Kata lainnya yang mengalami pelesapan fonem adalah main. Kata ini pada bahasa Hitu, Wakal, dan Hila memiliki bentuk yang sama, yaitu pahai yang terdiri atas susunan fonem $/ \mathrm{p} /, / \mathrm{a} /, / \mathrm{h} /, / \mathrm{a} /, / \mathrm{i} /$. Sementara itu, pada bahasa Morela berbentuk pahaey yang terdiri atas susunan /p/, /a/, /h/, /a/, /e/, /y/. Pada bahasa Mamala, kata pahai dan pahaeymengalami pelesapan /p/ di awal kata sehingga menjadi ahai yang terdiri atas susunan /a/, /h/, /a/, /i/.

Berdasarkan kriteria penentuan kata kerabat/ cognate yang telah dipaparkan dan dengan menggunakan rumus penghitungan leksikostatistik maka persentase kekerabatan bahasa Hitu, Wakal, Morela, Mamala, dan Hila dapat dilihat pada tabel berikut ini. 
Tabel 7

Matriks Persentase Kekerabatan Bahasa

\begin{tabular}{|c|c|c|c|c|c|}
\hline$\%$ & Hitu & Wakal & Morela & Mamala & Hila \\
\hline Hitu & - & & & & \\
\hline Wakal & 84 & - & & & \\
\hline Morela & 81 & 77 & - & & \\
\hline Mamala & 87,5 & 82,5 & 86,5 & - & \\
\hline Hila & 90 & 82 & 78,5 & 84 & - \\
\hline
\end{tabular}

Di lihat dari tabel 7 di atas maka dapat diketahui bahwa terdapat sepuluh pasangan bahasa dengan tingkat persentase kekerabatan yang berbeda-beda. Kesepuluh pasangan bahasa tersebut adalah bahasa (1) Hitu-Wakal denganpersentase kekerabatan sebesar 84\%, (2) Hitu-Morela sebesar 81\%, (3) Hitu-Mamala sebesar 87\%, (4) Hitu-Hila sebesar 90\%, (5) Wakal-Morela sebesar 77\%, (6) Wakal-Mamala sebesar 82,5\%, (7) Wakal-Hila sebesar 82\%, (8) MorelaMamala sebesar 86,5\%, (9) Morela-Hila sebesar 78,5\% dan (10) Mamala-Hila sebesar $84 \%$.

Berdasarkan penjabaran di atas, tingkat kekerabatan kesepuluh pasangan bahasa tersebut dapat diurutkan dari tingkat persentase terbesar hingga yang terkecil. Untuk lebih jelasnya, urutan tingkat persentase kekerabatan kesepuluh pasangan kata tersebut dapat dilihat pada grafik persentase kekerabatan berikut ini.

\section{Grafik 1 \\ Persentase Bahasa Kerabat}
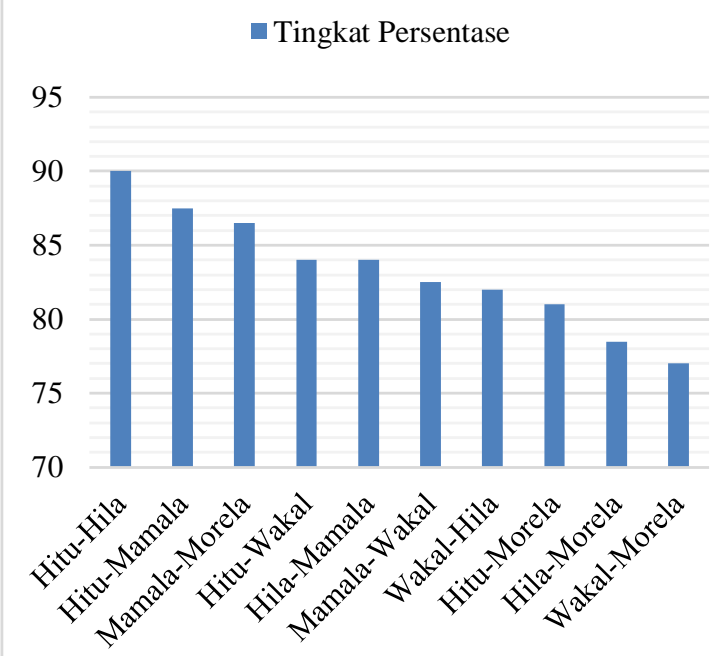

Dari grafik di atas, terlihat bahwa tingkat kekerabatan paling dekat hingga jauh berturut-turut adalah bahasa Hitu-Hila dengan persentase kekerabatan sebesar 90\%, disusul kekerabatan bahasa Hitu-Mamala dengan persentase $87,5 \%$. Tingkat kekerabatan selanjutnya adalah bahasa Mamala-Morela 86,5\%, bahasa Hitu-Wakal dan Hila-Mamala dengan persentase yang sama, yaitu $84 \%$, bahasa Mamala-wakal $82,5 \%$, bahasa Wakal-Hila $82 \%$, bahasa Hitu-Morela $81 \%$, bahasa Hila-Morela $78,5 \%$, dan bahasa dengan tingkat persentase terendah berdasarkan tabel 5 di atas adalah bahasa Wakal-Morela dengan persentase kekerabatan sebesar $77 \%$.

Dari penjabaran di atas dan mengacu pada teori yang dikemukakan oleh Crowley (2010), relasi genetis antara bahasa Hitu, Wakal, Morela, Mamala, dan Hila dapat ditentukan, yaitu antara bahasa Hitu-Hila, Hitu-Mamala, Mamala-Morela, Hitu-Wakal, Hila-Mamala, Mamala-Wakala, Wakal-Hila, dan Hitu-Morela dapat dikategorikan sebagai satu bahasa dialek, karena berada pada posisi $81 \%$ ke atas. Sementara itu, bahasa Hila-Morela dan Wakal-Morela dapat dikategorikan sebagai subkeluarga bahasa karena berada pada posisi $61-81 \%$.

\section{PENUTUP}

Dari hasil uraian dan analisis kriteria kekerabatan, dapat disimpulkan bahwa kekerabatan bahasa Hitu, Wakal, Morela, Mamala, dan Hila dapat ditinjau berdasarkanempat cara, yaitu (1) kata yang identik atau sama, yaitu kata-kata yang dari bentuk dan susunan fonem-fonemnya sama; 
(2) korespondensi fonemis, yaitu saling bertukarnya fonem-fonem tertentu dalam hal ini /b/-/p/, /y/-/wa/, /k/-/t/, /s/-/y/, dan /l/$/ \mathrm{y} / ;(3)$ kemiripan secara fonetis, yaitu fonem-fonem yang berada pada posisi artikulatoris yang sama, yakni $/ \mathrm{n} /-/ \mathrm{n} /, / \mathrm{n} /-/ \mathrm{n} /-$ $/ \mathrm{m} /$ pada posisi nasal, /k/-/t/ pada posisi hambat (letup), /r/-/l/ pada tempat artikulasi apikoalveolar, /b/-/p/ pada tempat artikulasi bilabial; (4) satu fonem beda, yaitu pasangan kata yang hanya satu fonemnya berbeda, yakni $/ \mathrm{m} /-/ \mathrm{y} /, \quad / \mathrm{n} /-/ \mathrm{n} /, \quad / \mathrm{n} /-/ \mathrm{y} /, \quad / \mathrm{r} /-/ \mathrm{l} / ;$ (5) pelesapan fonem, yaitu ada fonem-fonem tertentu yang mengalami pelesapan di awal kata, yakni /y/, /i/, /p/, pelesapan di tengah kata, yakni $/ \mathrm{h} /$, /a/, dan pelesapan di akhir kata, yakni $/ \mathrm{y} /$.

Selanjutnya dari hasil perhitungan persentase kata kerabat dengan menggunakan rumus leksikostatistik, dapat disimpulkan bahwadari keseluruhan bahasa yang dianalisis, persentase kekerabatan bahasa yang terbesar berada pada bahasa Hitu-Hila dengan persentase kekerabatan sebesar 90\%. Berdasarkan persentase ini, bahasa Hitu-Hila dikategorikan sebagai satu bahasa dialek. Sementara itu, bahasa dengan tingkat persentase terendah adalah bahasa Wakal-Morela dengan tingkat persentase sebesar $77 \%$. Berdasarkan persentase ini, bahasa Wakal-Morela dikategorikan sebagai subkeluarga bahasa.

\section{DAFTAR PUSTAKA}

Alijah, Sitti. 2016. "Kekerabatan Bahasa Bugis dan Muna" Jurnal Humanika. No.16, Vol. 1. Semarang: Fakultas Ilmu Budaya Universitas Diponegoro

Anonim. 2011. Undang-Undang Dasar Republik Indoneesia Nomor 24 Tahun 2009 tentang Bendera, Bahasa, dan Lambang Negara, serta Lagu Kebansaan. Jakarta: Badan Pengembangan dan Pembinaan Bahasa Kementrian Pendidikan dan Kebudayaan.
Crowley, Terry. 2010. An Introduction to Historical Linguistics. Auckland: Oxford University Press.

Johnson, Keith. 2008. Quantitative Methods in Linguistics. Malden: Blackwell Publishing.

Keraf, Gorys. 1996. Linguistik Bandingan Historis. Jakarta: Gramedia Pustaka Utama.

2004. Komposisi: Sebuah Pengatar Kemahiran Berbahasa. Flores: Nusa Indah

Kridalaksana, Harimurti. 2008. Kamus Linguistik. Edisi Keempat. Jakarta: PT Gramedia Pustaka Utama.

Langgole, Nurdin. 1996. Leksikostatistik dai Dialektometri. Makalah Pada Temu Ilmiah dan Dialog Alumni Fakultas Sastra Unhas.

Nothofer, Bernd. 1990. “Tinjauan Sinkronis danDiakronis Dialek-Dialek Bahasa Jawadi Jawa Barat dan Jawa Tengah (BagianBarat)". Tulisan Ceramah dan Diskusioleh Pusat Studi BahasaBahasa Asia Tenggara-Pasifik. Yogyakarta: FakultasSastra UGM.

Simon, Johana Grace,dkk. 2015. "Kekerabatan Bahasa Alune dan Bahasa Wemale(Kajian Linguistik Historis Komparatif)". Jurnal Kajian Linguistik. Tahun II, No. 3. Manado: Universitas Samratulangi.

Sudarno, M. Ed. 1994. Perbandingan Bahasa Nusantara. Jakarta: Arikha Medika Cipta.

Sulistyono, Yunus dan Inyo Yos Fernandez. 2015. "Penerapan Teknik Leksikostatistik dalam Studi Komparatif Bahasa Barunusa, Kedang, dan Lamaholot di Nusa Tenggara Timur. Jurnal Pendidikan Humaniora. Vol. 16, No. 1. Malang: Universitas Negeri Malang.

Surbakti, Ernawati Br. 2014. Kekerabatan Bahasa Karo, Minang, dan Melayu: Kajian Linguitik Historis Komparatif. Jurnal Politeknik Negeri Lhokseumawe. Vol. 2, No. 1. 
Lhokseumawe: Politeknik Negeri Lhokseumawe.

Taufik. 2017."Deiksis Persona Bahasa Indonesia dialek Ambon". Jurnal Totobuang. Vol. 5, No. 2. Ambon: Kantor Bahasa Maluku.

Trask, R.L. 2000. The Dictionary of Historical and Comparative
Lnguistics. Edinburg: Edinburg University Press.

Wacana, Gitit I.P. 2013. "Relasi Kekerabatan Bahasa-Bahasa di Kabupaten Poso". Jurnal Kependidikan. Vol. 6, No.1. Poso: Universitas Sintuwu Maroso Poso. 